\title{
Sexual Violence, the Law of Silence and Building of Identity Process in the Adolescence. Psycho Affective Analysis of Two Real Life Rape Experiences in Cameroon
}

\author{
Aline Maguiabou Tchidjo ${ }^{{ }^{*}} \quad$ Vandelin Mgbwa $^{2}$ \\ 1.Faculty of Arts, Letters and Social Sciences, University of Maroua, PO box 644, Maroua, Cameroon \\ 2.Higher Teachers Training College, University of Yaounde I, PO box 47, Yaounde, Cameroon
}

\begin{abstract}
This contribution lies on the tracks and consequences of sexual violence situations and attack on the feminine identity directly went through and undergone by adolescents. If rape as an intrusion opens questions in suspense, revives enfolded wounds in the hope and necessity to make meaning emerge from it, it can also make other emergencies emerge, invent other landmarks to reinvent life, catch a glimpse of other horizons. Well, (re)build the self is not a matter of social engineering; it is before all, taking into account what makes link. The article is interested in the incidence of silence "accomplice" of the community on the victim of rape at the moment of realisation of developmental tasks. Some clinical semi directive talks carried out on two adolescents of RENETA (an NGO based in Yaounde, which receives and accompanies adolescent victims of rape) enabled us to obtain information on their personal story. The thematic analysis of verbatim revealed that silence around rape and the community's tendency on muzzling of the victim exacerbates trauma and particularly perturbs the unrolling of the identity process . The quest of feminine identity is "short - circuited" and the adolescent victim of social cruelty sticks in the realisation of developmental tasks.
\end{abstract}

Keywords: Rape, Accomplice silence, Identity narcissist suffering, developmental tasks

DOI: $10.7176 / \mathrm{JEP} / 11-28-10$

Publication date:October $31^{\text {st }} 2020$

\section{Introduction}

Rape constitutes, according to Scotto di Vettimo (2004), an extreme experience of violence in which the attack of the sexed identity, to the intimacy and human dignity relieves from an unformulable. Sillamy (2010) qualifies the criminal act in the sense that it literally comes to abrade the enrolment of the subject in his ontology and human condition. He does not pass an entire month, without audio-visual or social media taking note of a case of rape on a town or village of the country. If the phenomenon is a reality in Cameroon, no sociological reason nor administrative accountability of sexual aggressions, does not permit to believe that these sexual violence is a new phenomenon. All the social categories are concerned. The authors of rape are strangers to the victims, but in some cases they are relatives who are very close to the victims (father, uncle, cousin, brother).The victims belong to all the ages of life (childhood, adolescents, adult age, old aged), but the adolescence age is the most touched.

In 2004, during a briefing of journalists in prelude to the celebration of the $3^{\text {rd }}$ edition of the international day of the young girl on October $11^{\text {th }}$, UNICEF made his audience amaze by publishing the data which states that 60 adolescents on 100 are victims of sexual violence in Cameroon. Giving a percentage of $22 \%$ of girls aged between 15 and 19 years who had been forced into sexual intercourses (rapes); almost $60 \%$ of girls from 15 to 19 years had undergone sexual or physical violence experiences perpetrated by their men or husbands. https://acesfca.cm On the $1^{\text {st }}$ March 2019, during a workshop on sexual violence against children, held in the Yaounde II Sub Division (Mfoundi Division), officials of associations stood up to denounce rapes and sexual abuse on girls and women. At this occasion, statistics on cases censures daily in Cameroon, families, catchments, educational establishments and professional environments were communicated, it prevailed that half a million of Cameroonians are concerned in rape and sexual abuses. A most recent study reveals that in a population of 37.719 Cameroonian women and girls, $5.2 \%$ had been victims of rape, and almost a quarter amongst them had less than 10years at the moment of intrusion.

In the scope of psychoanalytical theory, Lacan had put in relation to this inaugural moment of forming of ego with this fundamental narcissistic experience that he designs under the name of stage of mirror, which marks a fundamental genetic and ontological stage, in so far as it will constitute the first draft of ego faced to the mirror, the child is going to anticipate in a specular and imaginary delusion, the apprehension of the mastery of her corporal imagination. His behaviour in front of her image in the mirror is characterised by the jubilatory assumption of her specular image by the being still deepen in motor powerlessness and the dependence of the nurturing who is the little man at this infant stage... (Lacan 1945, p.94). The child perceives in the image of his fellow being or in his proper specular image a form ("Gestalt") in which he will imaginarily anticipate the apprehension and the mastery of his corporal unit (Laplanche \& pontalis 1967). This unification is going to be brought into effect by the identification of the child to this image : it suffices to understand the stage of the mirror as an identification to the 
full meaning that the analysis at this end :notably the transformation produced in a subject, when he assumes an image (Lacan 1945,p.94).

It is therefore from other fellow beings of his kind that the instance of ego drafts and constitutes. This fundamental narcissist experience constitutes the symbolical mystery of what will be the ego. She is at the base of the imaginary experience of ego at once constituted as the "ideal- I" and root of secondary identifications (Lacan 1945). The beginning of this subjective structuring characterises the primary narcissism, that is to say the urge to the identification of the subject on himself, and on the image in which he identifies himself. As a result, the intersubjective relation marked by the effect of stages of mirror, is first an imaginary and dual relation, where the ego is constituted as one another and other people as alter ego.

One perceives that in the links of the subject and his fellow beings, deploys a real imaginary capitation of the double in so far as the subject compounds himself with his image (Mgbwa 2011).In effect, originally, it is like the other one-the other one of the mirror in its inversed structure that the child constitutes himself (primary narcissism) and it is the naming of the child by the mother. A mother whose gaze is gazing at him, which will enable access of the child to the symbolic register (secondary narcissism). It is in this light that Scotto di Vettimo (2004), and Mgbwa (2011), analyses the image of self of the adolescent who falls in trance. All the field of narcissism as founder of the image of child's body and of his narcissist status, from what is first of all the mother's love and order of the gaze laid on the child.

To Lacan whose analyses are repeated here by Sotto di Vettimo (2004), the ideal of ego elaborated from the image of the body in the mirror, constitutes the backing of the primary identification of the child to the other fellow being. One can say that it is this image which is fixed, such that the subject stops as ideal of ego. If rape as corporal and physical intrusion opens questions in suspense, revives buried wounds in the hope and necessity to make sense emerge from it, can it also let emerge other emergencies, invent other landmarks to reinvent life, catch a glimpse of other horizons? For as much as, (re)build the ego is not a matter of social engineering; it is before all, to take into account what makes link.

In Cameroon, the community has the tendency to represent rape as an event amongst many others, which have the tendency of passing away just like others. This deplorable observation was already that of Mbassa Menick (2002), Cameroonian psychiatrist, specialist of sexual violence questions on children and adolescents, who were affirming that if the child's word is facilitated and encouraged in western countries, it is feared and often repressed in Africa as soon as the victim's remarks are of a disturbing truth for the adults of the community or the family (Mbassa Menick 2002, p.61).

Parents reluctant to file a claim or to confide themselves to specialists for the following reasons : reconciliation or friendly arrangement and private mediation they carry out in return for financial compensations; refusal of a publicly displayed which will dishonour them ; ignorance of the rights of the victim; incapability to pay judiciary charges (Mbassa Menick 2000; GTZ 2009 ; RENATA 2011). From what springs out of a study carried out by GTZ (2009), most of the victims had the courage to open up to a relation, but these relations did not support and help them to recover. If these socio cultural barriers to the free expression of rape victims are still observed today, it is the proof that time has passed, but mentalities have remained fixed, obstinate to change.

Despite disposals taken by the Cameroon state, under the impetus of the civil society, for a legal caretaking of victims, the subject remains a taboo in numerous families and Cameroonian communities. The silence about rape endures, at the detriment of physical and especially psychological wounds that sexual violence inscribes on the victims.

We have had an experience of a young girl who had been raped by her paternal uncle. She had a child as a result of this, but we got wind of this case and we followed her up. We have had a big brake at the level of the family who believed family integration is necessary to heal wounds. As a result of fear, the shame of what might be said; they displaced the girl so that one can no more have traces of her.

Confide Jeanne Ntolo, of "the association of autonomous women of "briqueterie", a popular catchment of Yaounde town, situated in the second sub division, during the above mentioned workshop. Testimony collected by Emmanuel Jules Ntap of VOA Africa, March $1^{\text {st }} 2019$ https://www.voaafrique.com.

Adolescence is the moment by excellence of the moulding of identity, because puberty and psychological transformations that intervene at this stage requires of the subject the realisation of specific developmental tasks prior to guarantee the passage from childhood to adult age. (Audéta \& Voirol 1997; Falque 2003; Marcelli \& Braconnier 2008). But the formation of the feminine identity further makes the influence of interpersonal relations to intervene, the shoring of the mother in particular (Erikson 1975; Bydlowski 2010). Henceforth, what has become of the formation of feminine identity in a rape situation, mainly in a psychosocial context dominated by the absence of those living around them (parent, relations, community). Would the law of silence around rape inflame its impact on the psyche of the adolescent? What psych affective incidence can silence around rape unfolding around identity process to the adolescence? 


\section{Methodology}

The study had been carried out on two adolescent's victims of rape, censured at the head office of RENATA (National Network of Aunties Association), Yaounde antenna (located at "Santa Barbara"). RENATA is an NGO created by The German-Cameroonian program of Health/Aids of the German Cooperation for Development (ex GTZ), in 2005. It priority receives girl mothers (aunties, in the aim to give them a basic education in terms of sexuality and reproductive health), but also victims of rape (within the scope of the fight against rape, SOS - Rape). In the SOS-Rape cell in particular, one finds children, adolescents and a few young adults educated or not, workers or jobless.

Selected adolescents to participate in the study are Cameroonians victims of rape, aged from 16 to 18 years (period of identity crisis). They had all been sexually abused with vaginal penetration during adolescence, and rape constitutes the first sexual intercourse. The author of the rape is a family member. They have not benefited from a particular escort because the community to which they belong has decided not to negate rape, at least to deafen "the matter" to preserve the honour of the family, to escape from social stigmatisation. They haphazardly entered in to contact with the aunties of RENATA during one of their sensitisation campaigns and decided, themselves, to align to the program of fight against rape (SOS-rape), led by this local organisation.

The clinical method, based on semi directive talks, has enabled more collective and exhaustive data on the personal story of participants at the study: rape circumstances, social behaviour of the pseudo-shored, psychic life experience of the victim, identity process. The thematic analysis of verbatim from these talks has brought surprising information on the specificity of identity process in the adolescents in rape situation, in a context dominated by the law of silence. The discussion of data analysis has led to suggestions as concerns the community, civil and judiciary pick up charge, of this this specific adolescent profile.

\section{Results}

\subsection{The Case of Claire}

Claire is a young Cameroonian of 16 years, a student in a secondary school in Yaounde repeating form four class. Presently Claire lives with her parents and two junior brothers. But that has not always been the case in the past. Between 12 and 14 years, the adolescent was living with her paternal uncle, the author of her rape. In effect, at the age of 12 . Claire is called to leave the residence of her parents to live in the house of her father's junior brother whose wife has just got a first child, and needed assistance. Claire had been encouraged by her daddy to vacate for Bertoua town where the small family was living. The decision of his daddy was however welcomed, the adolescent underlines in these terms:

"It was my preferred uncle; he always kept us so many gifts every time he was arrived our house. And daddy is very strict. I have never gone out with my pals. Thus when he told me l had to go and live at my uncle's place...I was very happy". The first two years passed on well. Uncle was still the "kind uncle" and Claire was having a good relationship with her guardian. But everything changed an evening where Claire was found alone in the house with her uncle. Her mother has travelled for a family meeting in her village, a few kilometres away from Bertoua. "I will never forget this day", she declared just before pushing out sobs she was unskilfully struggling to repress: It was very hot in the night. And since there was no fan in my room, uncle...told me to come and sleep with him who was already sleeping, and so he began touching me. He woke me up and my heart started beating hard. He said I should not be afraid, that there is no problem, that it's normal for him to touch me. He asked me if I had already made love with a boy and I said no, He said he is going to show me how it is done, and as such when I'll get married I will have no problem to give birth.

Claire really loved her uncle because he has always been very good to her and with her brothers. He knew how to "spoil" them. Uncle therefore had a privileged place in the "heart" of the adolescent and he knew it, he uses this to achieve his animalist goals. Having become the tutelary authority of the young girl since 2years, he therefore had a certain psychological majority on this latter, which was enabling him to get what he wanted from her without seeing himself in any real resistance. After a pause of about 60 minutes and still with the head bowed on the floor, Claire continued to confide in us as follows:

He started undressing me. I was trying to refuse. But he was saying $g$ "I have never hurt you is it today that I will begin. Just remain calm and you will see that it is nothing», He had already removed the top. He quickly pulled my trousers.it was light so he succeeded in removing the trousers and the inner wear at the same time. I had no strength to talk. I was only crying and beating him. He continued as if there was nothing wrong. I had pans and I said uncle please am feeling pains. He continued.

Claire is being raped, but she remains polite, she remains submissive to the uncle. She knows that what he does is bad, but the position the uncle occupies in her psyche, this place that he has taken time to nourish, to maintain throughout years, weakens the vigour of the young girl and hinder her to oppose a vivid resistance to her tormentor. Thus enable the uncle to go to accomplish his nasty job. "When he finished, he put on his short and he laid down again". Claire excludes herself from the rape episode. She describes a scene in which she finds herself, but makes no mention of herself. She is therefore present on the rape scene without being there in reality. In effect she 
positions herself as a spectator of a film in which she has meanwhile participated. For sure she is there but not as an actress. It is proof that she rejects what has happened, that she has not adhere to the "unhealthy" project of the uncle and that she did not like being in the story. It is an indication of psychic suffering in a sexually abused adolescent.

As soon as the uncle liberated her, Claire left the room and went and lay in her room. She revealed having cried the whole night to us. She had bled and had so much pain in between her legs. At a certain hour in the night she heard her uncle remove the keys of the main door. She understood that he was hindering her from going out. It is then that she realised that the uncle himself knew that what he had done was bad and that if the adolescent left, he would incur the consequences. This act on the contrary motivated the young girl to seek for strategies to leave this house. But the next morning the uncle was aware of her project of leaving the house, and he threatened her. According to her, it was the first time her uncle is threatening her "He entered my room; he saw that I had packed my bag he was annoyed. He said that if I try to run that is where I would know him. He said that even if I tell people what had happened nobody will believe me and it is me who will be ashamed". The uncle was sure that he ran no risk, or was simply trying to intimidate the adolescent. After everything the uncle was quite right. Claire left her uncle house when the latter left for work. A friend helped her with transport money and she arrived Yaounde at midnight.

It is my father who opened the door. He asked me why I was arriving at night like this, I started crying. I was unable to tackle that subject. He called my uncle and my uncle told him that he drove me away because I was disorderly going out with boys in Bertoua. When I tried to explain the truth to my father he did not want to understand anything. He became so violent.

On the other hand, the mother of the young girl showed up to be more attentive to the version of her daughter. Claire testifies in these terms:

It is my mother who at least listened to me. I can say that she believed me. I showed her my wounds. She told me to go and lie down. The following day she came and met me in my room she told me that even if the uncle did that to me I had to remain quiet. She said that there are things that are not said aloud. It does not present well. She said that my father is going to settle that with my uncle. She gave a vaginal solution so as to carry out my private washing with it.

And it was the last time the subject was been tackled in the family. Neither the mother nor the father nor the uncle, nobody has never talked of Claire's rape in the family. Two years have passed like this without anyone in the family being preoccupied about what the adolescent was living within her since her sexual aggression. Meanwhile Claire was choking of desire to talk about it, to confide herself, to come out of the psychological malaise in which the experience of rape had installed her. She recounts:

My body had pain me a lot. After it past. Afterwards I had a lot of pains in my heart. My mother said it was gastric pain. Daddy was buying me medicines for gastric pain. It comes and it goes. It is no longer so much like before. Daddy is so stiff to remove his money. But for my gastric pain he always bought my medication.

Claire as such was suffering from psychic conflict linked to rape. Her parents undoubtedly knew something but chose to negate the affected at the benefit of physical, biological and the social relationship. "...Me I just wanted that my father listens to my version. All what I wanted was that my father calls my uncle, we sit everyone gives his version. As such the truth was going to come out. My father is the elder brother. Is an elder brother afraid of his junior brother?" And for the first time since the beginning of the talk, Claire set her gaze on us. She was waiting for an answer, a help, an ally, or a relieve. Claire was feeling lonely and disarmed in front of a psychological challenge so heavy her to carry. "My mother believes my story but she is afraid of my father. She is afraid that if she brings up the topic my father is going to be angry and can lay hands on her". Claire again bowed down her gaze, waits 30 to 40 seconds before continuing by throwing;

"I am not going to marry. It is of no use ... men are so violent. What we see on television in white's homes is better as compare to our situation. But here in our home it is as if we get married to suffering. I cannot get married to suffer". We had presented an imaged situation to Claire in which a very virtuous man- indeed desires her for a wife. She replied: "Me I cannot accept that a man touches me!" We had wanted to know her feelings in relation to maternity and the adolescent has this to say:

In any case the Aunties have promised to help me come out of this. They have said that my life is going to change, because to be real, nothing pleases me with regards to marriage. Even feasts I no longer attend. I no longer even have many pals beside me. For this reason I am always at home. I view. I also study even though school does not like me. I study, I forget everything again. But it is worthwhile that I should struggle and have my A/L (...) I will like to cater for abandoned children .that is work in an Orphanage or others.

Claire is not interested in activities that normally captivate girls of her age, due to her experience as a result to trauma linked to rape. She makes an experience of a sort of developmental rupture, which had prematurely make her pass to the adult stage, without having enjoyed the privileges of the adolescence: pleasure of life, carefree attitude, risk behaviour...She feels like an adult and thinks like an adult, she has a clear idea of her socio professional orientation. 
But the professional choice of Claire is directly linked to her experience of rape victim and social silence :she wants to take care of abandoned children, that is to say, "alone in the world", without the support of their parent, vulnerable, exposed to abuses, like the one she has experience herself.

Besides Claire so much counts on the psychological escort of RENATA. She is therefore not yet healed of the psychological wounds provoked by sexual aggression. Happily she at last has the opportunity to talk about it thanks to this association which is reaching out to her and that she will use as an object of consolidation. "It was Aunties who have made me to talk about the story again. I had never talked to anyone again about it. My mother had told me it does not present well. But it was choking me so much in my heart ". Claire has remained a prisoner of her story, with the complicity of her parents, and was suffering in silence.

\subsection{The Case of Blonde}

Blonde is an adolescent mother of 18 years, spinster, without job, living with her grandmother on whom she solely relies. It is in the capacity of girl-mother that she integrates RENATA, she needed to be accompanied having found herself prematurely pregnant one year after having been raped by her father - in law, conjoint of her mother, she was then 16 years. Blonde is the eldest in a family of four thus having three step brothers. When the mother of Blonde got marriage with the concern of her brothers, the adolescent already has 13 years and is normally educated. The family at this moment counts three members, Blonde, her mother and the concubine of her mother, who occupies the place of father in the life of the young girl. "I was calling him daddy. He was like my father. He was the one who was paying my school fees, feeding the house, in fact he was taking care of everything ". Blonde had not known her father and had suffered from this absence during all her infancy, particularly at the nursery and at the primary levels. She confides in us, "My friends loved to talk of their father. When you look at them you could feel the joy in the. But for me could not say anything, it made me feel uneasy". And so one day, a miracle happened, Blonde at last had "a father" and was happy about it. Like what people say, "better late than never". Everything was going on well in the small family until the day that the supposed father gravely went beyond the bounds of his tutelary authority on the adolescent. Blonde had almost 16 years and was entering the class of form five. The beginning of it all is when am bathing, he always open the door to spy me. He was saying either that he wants soap, or it is brush. So he always wanted something when I was bathing”. The tormentor of Blonde had therefore been peeping her during a certain time before crossing another limit of his perverse tendencies. Blonde recounts the circumstances of her rape in these terms:

He was sitting in the parlour while I was sweeping, but I observe how he fixed his gaze on me. After he asked me to come and sit beside him a little. He started caressing my thighs. He was saying "let yourself go let yourself go, you are a very beautiful girl, you please me so much" "I tried to get up ,but he caught my wrist strongly and he put me back on the bench. After he become kind again. He started touching me again. He was saying that he is able to make me travel after my G.C.E., that if I cooperate he will give me what I want.

The cunning of seduction through enticing promises was the privileged arm of the rapist in full criminal operation. The "father" of the young girl knew that she specifically loved school and was dreaming to go and pursue her studies abroad after her Advanced level; but her mother had the tendency of chilling her telling her that she does not have the means. It is this weakness that her tormentor used. It was surely flattering, but not enough to take the step over the moral values of the adolescent. She recounts:

I was struggling but he was blocking me. He stretched me on the bench again. He was strongly tightening my wrists. He climbed on me, he blocked my legs, he lifted up my skirt was dosing his shoulders. He continued, was huge I felt the pain and was saying please, please, please am going to shout and people will come. He pleaded with me not to shout but I kept on struggling". The situation was more than me to handle.

Blonde stopped there, head bowed; one would say she was counting her fingers. And thence she did not want to say anything despite all the strategies of revival that we used. We left her while making her to promise continuing the talk the next day. The lateness of Blonde the next day was yelling. She pretended having been retained by her baby. But it was clear that recounting her rape was difficult for the young girl. Two years were passed, but Blonde was still suffering from the scars of her sexual aggression. She started the story of this second day by flinging on us: "Madam I hope that you are not going to ask me to recount that - story again ". We encouraged her to pursue the recitation of the facts.

My mother had to spend one week where she had gone to. He knew. He was counting on that. I did not want to see him any longer. He asked me for excuses, that please I must not say it to anyone, that I can ask him anything that I want. I was not talking only cried for a long time. I was thinking of my mother, one heart told me to go to her house. I was afraid of him. When he was passing on the corridor my heart was beating. I spent all of that day in the room.

It is the next morning that Blonde found an opportunity to go away from the crime scene, to go to her grand mother's house. She stayed there till the return of her mother, without saying a word to the grand-mother. In front of the insistence of the grand-mother to make her go back, Blonde break the silence. The grand-mother resolved to inform the mother by telephone. But this latter did not shake her any further. The adolescent stays with the 
grand-mother up to this day. The mother has never brought up the topic of her rape and she continues to be in contact with the rapist. The grand-mother just told her not to blame her mother, this man has done so much for her and still continues to do more for the entire family. The only person who paid an attentive ear to Blonde's story is her ex-boyfriend, the father of her daughter. The muteness of her family on the topic of her rape kills her gently." ... my own mother has been able to choose a man as compared to her own daughter!" (She shouted in between two sobs) it pains me very much. If it was not my grand-mother I would have committed suicide I swear ". Pause of about two minutes, swinging the legs on her chair, the adolescent repeated:

It does not matter she has been blessed with her own marriage, but I believe God will exposed the husband. ... Here I am, with no life of my own. He has decayed my life. Have I even be living since that encounter? No all the men frighten me at a thought. It is only with that my friend that I was talking. He seems kind but not much different from the other men. A man remains a man, and is seen as coward in everything. Here am I with a baby. I no longer go to school, while he has continuing.

Blonde is no more feeling like a family member at all to this man whom she once happily called "daddy" at a certain period. He has become a stranger, he has betrayed her confidence. But the worst thing in the story, according to the young girl, is the silence of her mother and her indifference in front of the "painful" and "scandalous" experience that she had undergo. The adolescent confide having thought of filling a complaint to his tormentor after having learnt, at RENATA, that it was possible. But all that she was lacking were proves. Today she recommends herself to the "lord", hoping that a miracle will buttress the situation in a broad day and the one who haunts her nights, who has imprisoned my youthfulness shall undergo the social and legal consequences of his deed.

\section{Discussion}

Golse and Roussilon (2010) put in that all change of state give room for a sort of "developmental mourning", which translates the loss of the preceding state. This loss does not leave the subject indifferent and requires a work of adaptation on its own to change and the recovery of a new equilibrium. They in effect write that every new stage of development requires the loss of a preceding equilibrium, and the search of a new psychic position, which corresponds to a change of state which does not go on its own, whatever might be the kindness of change considered. (Golse \& Roussilon 2010, p.212).

The experiences of the two adolescents, Blonde and Claire, rightly show a developmental rupture. Rape by aggressing the body has affected its uniqueness of violence. Henceforth the body is mistaken and given the impression of a soiled object, object of displeasure, object of internal incoherence. The adolescent ego appears partitioned, cleft (Anzieu 1995). The victim makes the experience of broken mirror, to borrow from the Lacanienne approach of the image of the body (Lacan 1945). So the image of the body sets up the identity (Rajablat 1995). How to build one's stable identity when the body, basic element of the process, has become insensitive, painful, libidinal disinvested, desexualised, neglected, rejected, de-valorised, depreciated? Kaës (2014) notably in the social makes the observation that the unconscious alliances lie on met psychic and met asocial guarantors. He thinks the individual psyche is surrounded by the met psychic guarantors of the psychological life. The alliances, agreements and structuring contracts also exercise this function of meta for every subject of a link configuration. Kaës (1990 2014, p.9) proposes, to face a crises, of the shore on the group. It is in effect through crisis as he recognises that comes the necessity to seek for support, to find reinforcement and reassurance: through disturbance also comes dynamisms, so as to create new regulations and find pleasure in it. So, rape as a psychological or social catastrophe, affects unconscious alliances in diverse manners, at the level where meta-psychological guarantors constituted social, cultural and political framework are failing or devastating. Kaës (1990) furthermore insists on the dimension of shoring as result of a crisis situation, and as a support which enables the subject to bounce back after blow. Shoring therefore will enable the subject to recover psychological equilibrium fractured by an experience of crisis. He completes the objects of shoring identified by Freud and proposes, instead of three, four forms of shoring, shoring on the body, shoring on the mother, shoring on the group and shoring on self (autoshoring). Kaës (1990 p. 9-10) in effect poses the hypothesis of a multiple exposure of the psychic. This hypothesis means that all psychological moulding is multi-shoring and that remarkable qualitative variations in this moulding occurs from the moment that certain shoring are failing ... The Freudian model of choice of objects by shoring suggests a representation of the process of multiple shoring, that is to say: the transformer retake of the shored by the shore in an intermediary space of shoring that we can imagine as a sieve of communication or isolation between two heterogeneous spaces.

The content analyses of the two adolescents' speeches studied prove that the experience of rape while aggress the body affects the psychic of the victim. But again, the law of silence which characterises families protects the rapist and as a result imprisons the victim in a symbolical "prison", which hinders him from subscribing in a psychological healing, The developmental task assigned to the adolescence, notably the quest for identity, is vanished, to the benefit of preoccupations related to adult age, without that the adolescent forcefully be psychological ready to assume them. As such, rape in harassing the body "injures", "castrates" the psychic and 
compromises its functioning. The disarmed subject, stays alone in this psycho affective, laboriously invests himself in a psychic elaboration process of ego which ends up in a sort of deconstruction of the identity process, the adolescent throwing herself through challenges that do not correspond to her age. Rape therefore appears as a developmental rupture which prematurely transports the victim from the adolescent stage to the adult stage.

Claire, raped at 14 years, leave her with any interest for the pleasures of life. She has like lost the taste to be a young girl, and already thinks of building herself a social and professional identity. The adolescent has the feeling of having lost her youthfulness, independent of her will. She hopes henceforth to be able to catch up this breach by deciding for her carrier to come. But her choice of carrier betrays her psychic suffering; and maintains her in the posture of prisoner victim of her experience. The reason is that Claire has never benefited from a psycho affective follow up from her close relations after her sexual violence. How in this state could she build herself a stable identity? According to Mussen (1980, p.14) in effect, when the subject is evaluated at her real value, that contributes to the good functioning and the forming of the identity feeling.

Unlike like Claire, Blonde must have carried the burden of her sexual harassment alone, meanwhile perpetrated by a family member, very close to her mother. The adolescence tried herself to give meaning to her life, but could she arrive at it without the support of the main shorer whom she needed to come out of this: her mother. Like Claire again, Blonde quickly passed from adolescent preoccupations to adult preoccupations. One year after the rape, she got pregnant. The quest for feminine identity, inherent to adolescence, is short circuited by the quest for maternal identity. But has she conquered this maternal identity? No, she did not have the necessary psychological tools. According to Tap (1980, p.8) in effect,

My identity is ... what render me similar to myself and different from other, it is that through which I feel myself exists as a social figure (roles, functions), that through which I define and know myself. Feel accepted and recognised as such by others, my groups and my belonging culture.

The feeling of maternal identity for an adolescent mother shall therefore consist to perceive herself and to define herself as such from the pregnancy and within time. She as such would say while talking about herself "I am a mother who is happy of my state and I am pleased in it". This is not at all the case for Blonde who finally seems to regret to have become mother. It is as many empirical arguments that plead in favour of what rape is, and its denial by the community to which the adolescent belong which has installed her in some sort of fish trap identity. Erikson (1972) talks of "confusion of identity" if there is no integration of body image, self-image and of the continuity in the representation that the subject has of himself. In effect Blonde is faced with two developmental crises in the midst of which is found an experience of rape denied by the family and such a burden trailed by the adolescent. The author of Blonde's pregnancy is the only person who showed concern to her story. In the "urgent" need of a shorer with the critical situation she was going through, all alone, Blonde "innocent", abandoned herself to this boy still a "child" also. The proof he is unable to ensure the responsibility of his paternity. The experience of Blonde's maternity comforts the fact that the idea according to which "To become mother is built" (Benhaïm 2011, p.94), but this building is done by shoring on an emotionally invested "object". The choice privileged by the adolescent in a premature pregnancy situation is the mother. In this light, Bydlowski (2010) supports that it is necessary for the future mother to be accompanied by "a network of women" at the forefront of which her mother should help her notably face this unconscious aggressiveness that she made the experience. She writes on this subject:

A woman cannot bear her maternity alone, she needs eminent individual. Moreover, this experience necessitates the help and warmth of other women, mother sisters, or cousins, see colleagues, other women who incarnate the current reality an represent references in the past. The identification to a positive maternal image is a necessity to the young woman who expects a child. (Bydlowski 2010.p.20).

\section{Conclusion}

The analysis of the life story of the two cases studied has enabled us to formulate the hypothesis in line with the function of maternal shoring in the first place, then community as follows is determinant for the unrolling of identity processes to adolescence, it is more and more in the case of rape, because the victim, attained in her corporal integrity, is found disarmed as regard the building of a stable identity. The body that has been built assembled and figured as a libidinal body, a body of pleasure is, from the fact of intrusion, uninhabited, insane and at last in quest of insane pleasures. In front of this sad reality, the adolescent questions herself and calls, without response this Other which sends her back to her proper narcissistic identity sufferings and the knock to her own limitations.

It is therefore urgent that the Cameroonian society in particular be sensitised on the matter. It is the first level of intervention. The first level consists to provide the community with necessary psycho social tools for the effective and efficient management of the youth. An initiative of parental education might be envisage in the community perspective to accompany the youth on the path to emotional stability, of social success and professional insertion. Channels to privilege might be to go down to the field, social and audio-visual Medias. Such an enterprise will convert psychic suffering into a social suffering which, according to Käes $(1990 ; 2014)$ and his followings, is more 
suitable to lead the subject towards psychological healing, comforted by the fact that she is not alone to sustain her suffering.

\section{References}

Anzieu, D. (1995). Le moi peau. Paris, France: Dunod.

Audétat, M.-Cl \& Voirol, Ch.1997.L'adolescent. Neuchâtel: Psynergie.

Benhaïm, M. (2011). L’ambivalence de la mère. Toulouse: Éditions érès.

Bydlowski, M. (2010). Je rêve un enfant. L'expérience intérieure de la maternité. Paris : Odile Jacob.

Erikson, E. H. (1972). Adolescence et crise. La quête de l'identité. Paris: Flammarion.

Falque, O. (2003). “ « Le dieu des adolescents. » Fonction du religieux et processus d'adolescence”, Imaginaire et Inconscient, 11 (3), 129-144.

Golse, B. et Roussillon, R. (2010). La naissance de l'objet. Paris: Presses Universitaires de France.

GTZ (RENATA) (2009). Viol et Inceste au Cameroun. Rapport final.

Guettier, B. (2001). "Grossesse, maternité : circuit court ou court-circuit? ", La lettre de l'enfance et de l'adolescence, 3 (45), 67-71.

Kaës, R. (1990). "Introduction à l'analyse transitionnelle”. In R. Kaës, A. Missenard, R. Kaspi, D. Anzieu, J. Guillaumin, J. Bleger, E. Jaques (dir.), Crise, rupture et dépassement, 1-83. Paris: Dunod.

Kaës, R. (2014). Les alliances inconscientes. Paris : Dunod.

Lacan,J.(1945). "Le stade du miroir comme fondateur de la fonction du Je", Ecrits, 93-100

Laplanche J. \& Pontalis J.-B. (1967). Vocabulaire de la psychanalyse. Paris: Presses Universitaires des France.

Lopez, G. \& Filizzola, G. (1996). Le viol. Paris, France: Presses Universitaires de France.

Malrieu, P. (1980). "Genèse des conduites d'identité". In P. Tap (dir.), Identité individuelle et personnalisation (p. 38-51). Toulouse : Privat.

Marcelli, D. \& Braconnier, A. (2008). Adolescence et psychopathologie (3e éd.). Paris: Elsevier Masson.

Mbassa Menick, D. (2002). "Les abus sexuels en milieu scolaire au Cameroun. Résultats d'une recherche-action à Yaundé", Médecine Tropicale, 62, 58-62.

Melo (2006). Adolescentes enceintes", Adolescence, 55 (1), 141-174.

Mgbwa, V. (2011). "Image de soi de l'adolescente qui tombe en transe dans les établissements scolaires", SYLLABUS, 2(2)129-162.

Mouras, J.-P. (2004). "Être mère à l'adolescence", Figures de la psychanalyse, 1 (9), 97-101.

Mussen, P. (1980). "La formation de l'identité. Découvertes psychologiques et problèmes de recherche”. In P. Tap (dir.), Identité individuelle et personnalisation (p. 13-21). Toulouse: Privat.

Ndonko, F. (2003). Projet "Tantines" : Comment les filles-mères s'engagent dans la prévention des grossesses précoces et du VIH/SIDA auprès des adolescentes dans leur communauté au Cameroun. Récupéré du site du Magazine de la Coopération Germano-Camerounaise. [Online] Available: http://www.cameroun-plus.com

Poussin, G. (2004). La fonction parentale ( 3 éd.). Paris: Dunod.

Rajablat, M. (1995). L'image du corps. [Online] Available: http://www.serpsy.org

Scotto di Vettimo,D.(2004). "Psychopathologie de la honte chez les sujets victimes de sévices sexuels : quels enjeux cliniques et thérapeutiques ?"Rev.Latinoam, Psicopat, Fund, 7 (2), 49-82

Sillamy, N. (2010). Dictionnaire de psychologie. Paris: Larousse.

Tap, P. (1980). Identité individuelle et personnalisation. Toulouse: Privat.

${ }^{1}$ Aline Maguiabou Tchidjo, Ph.D in developmental Psychology, Lecturer, University of Maroua, Department of Philosophy and Psychology.

${ }^{2}$ Vandelin Mgbwa, Ph.D in Psychopathology and Clinic, Senior Lecturer, University of Yaounde I, Higher Teachers Training College. 